\title{
Serahsî̀nin Debûsî ve Pezdevînnin Usûl Eserlerindeki Bazı Görüşlerine Yönelik İtirazları ve Bu İtirazlar Bağlamında Usûlü's-Serahsî̀nin Temel Kaynaklarına Dair Bir Değerlendirme
}

\section{Serahsî̀s Objections to Some of Debûsî̀s and Pezdevî̀s Views in Their Usûl Works and an Assessment of Main Sources of Usûlü's-Serahsî in the Context of These Objections}

\author{
Abdurrahman Bulut \\ Arş. Gör. Kocaeli Üniversitesi, İlahiyat Fakültesi, Fıkıh Anabilim Dalı \\ Research Assist., Kocaeli University, Faculty of Theology, Department of Fiqh \\ Kocaeli / Turkey \\ abulut_89@hotmail.com | https://orcid.org/0000-0003-4631-7911
}

Article Type / Makale Tipi

Research Article / Araştırma Makalesi

DOI: $10.33420 /$ marife. 900571
Article Information / Makale Bilgisi

Received / Geliş Tarihi: 21.03.2021

Accepted / Kabul Tarihi: 12.04.2021

Published / Yayın Tarihi: 30.06.2021

Cite as / Atıf: Bulut, Abdurrahman. “Serahsî’nin Debûsî ve Pezdevî'nin Usûl Eserlerindeki Bazı Görüşlerine Yönelik İtirazları ve Bu İtirazlar Bağlamında Usûlü's-Serahsînin Temel Kaynaklarına Dair Bir Değerlendirme”. Marife 21/1 (2021), 521-540. https://doi.org/10.33420/marife.900571

Plagiarism / Intihal: This article has been reviewed by at least two referees and scanned via a plagiarism software. / Bu makale, en az iki hakem tarafından incelendi ve intihal içermediği teyit edildi.

Copyright / Telif Hakkl: "This article is an open access article distributed under the terms and conditions of the Creative Commons Attribution-NonCommercial-NoDerivatives 4.0 (CC BY-NC-ND 4.0) International License." / "Bu makale Creative Commons Alınt-GayriTicari-Türetilemez 4.0 (CC BY-NCND 4.0) Uluslararası Lisansı altında lisanslanmıştır." 


\section{Serahsî̀nin Debûsî ve Pezdevî'nin Usûl Eserlerindeki Bazı Görüşlerine Yönelik İtirazları ve Bu İtirazlar Bağlamında Usûlü's- Serahsînnin Temel Kaynaklarına Dair Bir Değerlendirme}

\section{Özet}

Hanefî usûl literatürünün ilk kapsamlı eseri Cessâs'a ait el-Fusûl fi'l-usûl'dür. Bu eser, Hanefî mezhebi imâmlarından kendi dönemine kadarki usûl birikimine dair önemli bilgiler ihtiva etmektedir. Daha sonra Debûsî, Takvîmü'l-edille isimli eserinde Cessâs'ın eseri başta olmak üzere Hanefî usûl düșüncesine dair mevcut birikimi sistematik bir șekilde nakletmiș, özellikle konu tasnifi ve kavramlar bakımından kendi katkıları ile yeniden şekillendirmiştir. Bu iki eser Hanefî usûl literatürünün kurucu metinleri olarak kabul edilmekle birlikte sonraki literatüre etkisi bakımından öne geçen iki eser Usûlül-Pezdevî ve Usûlü's-Serahsî olmuştur.

Serahsî, Hanefî usûl literatürünün iki klasik eserinden biri olarak kabul edilen Usûl adlı eserinde mezhep içi ihtilaflı meseleleri de nakletmekte ve kendisinden önceki Hanefî usûl âlimlerinin bazı görüş ve değerlendirmelerine yönelik itirazlarda bulunmaktadır. Naklettiği bazı görüşleri "hatalı" olarak nitelendirerek eleștiren Serahsî bu meselelerdeki șahsî görüş ve tercihini de "Bana göre", "Bu konudaki sahih görüş" vb. sarih bir ifade ile belirtmektedir. Serahsî naklettiği mezhep içi ihtilaflı meselelerin bir kısmında Kerhî, Cessâs ve Halvânî gibi bazı Hanefî âlimlerin ismini zikrederek görüşünü nakledip bu görüşü tercih etmediğini ifade etmekte ve ilgili meseledeki şahsî görüşünü belirtmektedir. Yine bazı meselelerde bir bölgenin meșâyıh grubuna işaret ederek mesela "Irak meșâyıhına" itiraz etmektedir. Usûlü's-Serahsî'deki mezhep içi ihtilaflı meselelere ve Serahsî̀nin bazı Hanefî usûl âlimlerinin görüşlerine yönelik itirazlarına dair dikkatli bir șekilde takip edilmesi gereken iki kavram "ashâb" ve "meşâyıh"tır. Serahsî, pek çok meselede "meșâyıhımızdan birisi (bazıları)", "meșâyıhımızın müteahhirûn âlimlerinden birisi (bazıları)" bazen de "ashâbımızdan birisi (bazıları)" șeklinde görüş sahibinin ismini zikretmeksizin Hanefî bir âlime nispet ederek naklettiği görüşü eleştirmekte veya zikredilen görüşü tercih etmediğini ifade edip kendi kanaatini belirtmektedir. İlgili meselelerde Serahsînnin şahsî kanaatinin ne olduğu önemli olmakla birlikte görüş sahibinin kim olduğunu belirtmeksizin naklettiği görüşlerin hangi Hanefî âlime ait olduğunun tespit edilmesi de Hanefî usûl tarihi açısından önem arz etmektedir. Nitekim bu eser boyunca muhtelif meselelerde ve farklı bağlamlarda zikredilen bu itirazların hangi Hanefî âlimin görüşüne yönelik olduğunun tespit edilmesi Usûlü's-Serahsî'nin temel kaynaklarına dair yapılacak değerlendirmeler için de bir malzeme teșkil edebilir. Bu alandaki bazı araștırmalarda Serahsî̀nin Takvîmü'l-edille'den yararlandığı fakat bununla birlikte bazı açlardan bu eseri "revize ettiği" ifade edilmiştir. Bununla birlikte Serahsî́nin Debûsî'nin eserinden hangi ölçüde yararlandığı ve bu esere yönelik tutumuna dair daha net bilgi sahibi olabilmek için bu iki eser arasında kapsamlı bir mukayese yapılmasına ihtiyaç bulunduğu ifade edilebilir.

Aynı dönemde ve aynı bölgede yaşamış olan Pezdevî ve Serahsînnin usûl eserleri arasındaki benzerlik de bu sahadaki bazı araștırmalarda ele alınmıştır. Bu iki eser arasındaki ilişkinin ne olduğu sorusuna dair bazı araştırmacılar tarafindan önemli kanaatler ifade edilmiş olmakla birlikte bu konudaki değerlendirmeler henüz tahmin düzeyinde ifade edilmiş olup daha net tespitlerin yapılabilmesi için bu meseleye dair farklı açılardan da bazı araştırmaların yapılması gerekmektedir. Bu makalede usûl literatüründeki mezhep içi ihtilaflı meselelerin bu konuda bize bir malzeme sunduğu gösterilmeye çalışılacaktır.

Usûlü's-Serahsî'de Debûsî ve Pezdevî́nin isimleri hiç zikredilmemektedir. Bununla birlikte Serahsî'nin açıkça isim zikretmeksizin itiraz ettiği bazı görüşlerin kendisinden elli küsur sene önce vefat etmiş olan Debûsî̀ye, bazılarının ise kendisi ile aynı bölgede yetişmiş olan ve vefat tarihleri de birbirine çok yakın olan Pezdevî’ye ait olduğu ilgili meselelerin bu iki âlimin eserlerindeki görüş ve açılamaları ile mukayese edilmesi durumunda tespit edilebilmektedir. Bu çalıșmada Serahsî̀nin, Debûsî ve Pezdevî’nin görüşlerine yönelik itirazları tespit edilerek bu itirazlar bağlamında Serahsînnin usûl eserinde Debûsî ve Pezdevînnin eserlerinden istifadesi ve bu eserlere yönelik tutumuna dair bir değerlendirme yapılacaktır. Serahsînnin naklettiği mezhep içi ihtilaflı meseleler arasında yer alan hüsün-kubuh, illetin tahsisi, orucun vücub sebebi, (ؤ edatının vazedildiği anlam, iktizâ ile hazf ayrımı, nassın işareti ile sabit olan mananın tahsisi, bidat ehlinin muhalefetinin icmanın gerçekleşmesine etkisi, bazı hadis türlerinde mana ile rivayet, yazılı bir metnin rivayeti ve şart edatının anlamı gibi bazı meselelerde ismini zikretmeksizin görüşüne itiraz ettiği kişinin Debûsî olduğu görülmektedir. İstihsan ile hüküm verildiğinde kıyas ile amelin hükmü, illet türlerinden sebebe benzeyen illet, çocuk 
hakkında vücub ve çocuğun talak hakkı gibi bazı meselelerde ise Serahsînnin isim zikretmeksizin görüșüne itiraz ettiği kiși Pezdevî'dir.

Anahtar Kelimeler: İslam Hukuku, Usûl, Serahsî, Debûsî, Pezdevî.

Serahsî's Objections to Some of Debûsî's and Pezdevî's Views in Their Usûl Works and an Assessment of Main Sources of Usûlü's-Serahsî in the Context of These Objections

\section{Summary}

The first comprehensive work of Hanafi usûl (legal theory) literature is Cessâs's al-Fusûl fi'l-usûl. This work contains important information about the tradition of the imâms of Hanafi madhab (school of law) up to the author's time. Later, Debûsî conveyed the existing knowledge of Hanafi usûl thought, especially the work of Cessâs, in his work named "Taqwimul Adillah" and reshaped it with his own contributions in terms of subject classification and concepts. Although these two works are accepted as the founding texts of the Hanafi usûl literature, the two prominent works in terms of their impact on the later literature are Usûlü'l-Pezdevî and Usûlü's-Serahsî.

Serahsî, in his work named Usûl, which is considered as one of the two classical works of the Hanafi usûl literature, narrates the controversial issues within the sect and makes objections to some of the views and evaluations of the Hanafi scholars preceded him. Serahsî, who criticizes some of the views he conveyed as "erroneous", also gives his personal opinion and preference on these issues by using phrases such as "According to me", "Authentic opinion on this issue is" etc. Serahsî stated that he did not prefer the views of some Hanafi scholars such as Kerhî, Cessâs, and Halvânî in some of the controversial issues within the sect and expresses his personal opinion on the relevant issue. Moreover, on some issues, he objects to the mashayiqh of a region, by pointing to the region for example "Iraqi mashayiqh (jurist scholars)". The two concepts that should be followed carefully regarding the controversial issues within the sect in Usûlü's-Serahsî and the objections of Serahsî to the views of some Hanafi scholars are "ashâb (companions)" and "mashayiqh". In many issues, Serahsî criticizes the view that he conveyed by referring to a Hanafi scholar without mentioning the name of the opinion holder with phrases such as "one (some) of our mashayigh", "one (some) of our late jurist scholars (mutaakhirun)" and sometimes "one of our ashâb" and expresses his own opinion on the issue. Although it is important what the personal opinion of Serahsî is in the related issues, it is also important in terms of the history of Hanafi usûl literature to determine to which Hanafi scholar the views he conveyed without specifying who the opinion holder is, belongs to. As a matter of fact, the determination of which Hanafi scholar's opinion are the objections mentioned in various issues and different contexts throughout this work can also offer possible answers to the question of what the main sources of Usûlü's-Serahsî are. In some research studies in this area, it was determined that Serahsî benefited from the Taqwimul Adillah, but also revised this work in some ways. However, it can be stated that to what extent Serahsî benefited from Debûsî's work, and to have clearer information about his attitude towards this work, a comprehensive comparison is needed between these two works.

The similarity between the usûl (legal theory) works of Pezdevî and Serahsî, who lived in the same period and the same region, has also been discussed in some studies in this field. Although some researchers have expressed important opinions on the question of what the relationship between these two works is, the evaluations on this issue have yet to be expressed at the level of estimation, and some studies on different aspects of this issue need to be made to make clearer determinations. In this article, we will try to show that the controversial issues within the sect in the usûl literature provide us with material on this subject.

The names of Debûsî and Pezdevî are not mentioned at all in Usûlü's-Serahsî. However, some of the views that Serahsî objected to without mentioning his name explicitly, belonged to Debûsî, who died fifty years before him, and to Pezdevî, who was raised in the same region with him and whose dates of death are very close to each other, are can be determined by comparing the opinions and explanations in their work. In this study, the objections of Serahsî to the views of Debusî and Pezdevî will be determined, and in the context of these objections, an evaluation will be made about the use of Debûsî and Pezdevî's works and their attitude towards these works. It is seen that the person whom he objected to his opinion without mentioning his name is Debûsî on some issues such as husun-qubuh, tahsisu'l-illah, the reason for the fasting, the meaning of the preposition ( 9 ), the distinction between iktizâ and hazf, the effect of the opposition of ahl al-bid'ah on the ijma(consensus), the narration of a 
written text and the meaning of the conditional preposition. The person whom Serahsî objected to his opinion on some issues such as the judgment of analogy with istihsan, the vucub about child and the child's right to talaq, without mentioning his name is Pezdevî.

Keywords: Islamic Law, Usûl, Serahsî, Debûsî, Pezdevî.

\section{Giriș}

Hanefî usûl düşüncesine dair sistematik ve kapsamlı eserler hicrî dördüncü asır itibariyle telif edilmeye başlanmıştır. Cessâs'ın ö. (370/981) el-Fusûl fi'l-usûl isimli eseri -öncesinde usûlün bazı konularına tahsis edilmiş eserler mevcut olmakla birlikte- bu literatürün kapsamlı ilk örneğini teșkil eder. Cessâs bu eserinde şahsî fikirleri yanı sıra özellikle hocası Kerhî ö. (340/952) aracılığıyla Hanefî imâmlarından kendi zamanına kadarki Irak Hanefî çevresinin usûl birikimini nakletmektedir. Daha sonra Mâverâünnehirli Hanefî usûl âlimi Debûsî ö. (430/1039) Cessâs'ın eserinden de istifade ile Irak Hanefî usûl birikimini özlü bir şekilde nakledip kendi katkıları ile zenginleștirmiştir. Debûsî'ye ait olan Takvîmü'l-edille, özellikle kavramsallaştırma ve tasnif açısından bu alana getirdiği pek çok katkı sebebiyle literatürde özel bir yeri haizdir. ${ }^{1}$

Cessâs ve Debûsîyye ait bu iki eser Hanefî usûl düşüncesinin "kurucu metinleri" olarak kabul edilmektedir. ${ }^{2}$ Özellikle konu başlıkları ve temel kavramları itibariyle Hanefî usûl düşüncesinin teşekkülü bu iki eser ile önemli ölçüde tamamlanmış olmakla birlikte sonraki literatüre etkisi bakımından öne geçen iki isim Pezdevî ö. (482/1089) ve Serahsî ö. (483/1090) olmuştur. Bu bakımdan Usûlü'lPezdevî ve Usûlü's-Serahsî Hanefî usûl düşüncesinin klasikleri olarak kabul edilmektedir. Pezdevî ve Serahsî, Cessâs'ın ve Debûsînnin eserlerinden yararlanmış olmakla birlikte önemli ölçüde Takvîmü'l-edille'deki muhteva ve sistematiği takip etmişlerdir. ${ }^{3}$

\section{Usûlü's-Serahsînin Temel Kaynakları}

Günümüzde Hanefî usûl tarihine dair yapllan araştırmalarda, Usûlü'sSerahsî̉ de temel kaynak olarak yararlanılan eserlere ilişkin bazı değerlendirmeler yapılmıştır. Genel bir kanaat olarak gerek Pezdevî'nin gerekse Serahsî'nin Takvîmü'l-edille'den önemli ölçüde yararlandığı ve bu eseri takip ettikleri ifade

1 Bu iki metnin karşılaştırılması neticesinde Debûsînnin, genel çerçevesi itibariyle büyük ölçüde Cessâs'ın el-Fusûl'ünü izlediği ifade edilmektedir. bk. Mürteza Bedir, "Takvimü'l-edille", Türkiye Diyanet Vakfi İslam Ansiklopedisi (İstanbul: TDV Yayınları, 2010), 39/493) Debûsî, mutlak emrin وأما أبو بكر : zıddında ne gerektirdiği meselesini ele alırken Cessâs'ın "usûl" eserine atıf yapmaktadır الجحصاص فقد ذكر في أصوله bk. Ebû Zeyd Debûsî, Takvîmü'l-edille, thk. Halil Muhyiddin el-Meys (Beyrut: Dâru'l-Kütübi'l-İlmiyye, 2001), 48. Debûsînin Hanefî usûl düşüncesine katkılarına dair bk. Hacer Yetkin, Hanefì Usûlünün Kurucularından Debûsî ve Usûl Anlayışı, (İstanbul: Marmara Üniversitesi İlahiyat Fakültesi Vakfı Yayınları, 2017), 131-234.

2 Bedir, "Takvîmü'l-edille", 39/493.

${ }^{3}$ Mürteza Bedir, Fikıh Mezhep Sünnet: Hanefì Fıkıh Teorisinde Peygamber'in Otoritesi (İstanbul: Dem Yayınları, 2017), 43-44, 49-52, 146. Yazar, Pezdevî'nin eserinin "konu düzenlemesi ve sistematik açısından" Serahsî̀nin eserinin ise "geniş ve ayrıntılı olması ve analitik niteliğiyle" Hanefî usûl literatürünün klasik dönemdeki zirvesini teșkil ettiklerini ifade etmektedir. 
edilmektedir. Debûsî'nin usûl düşüncesine dair yapılmış olan bir araștırmada Serahsî'nin usûl eseri için “âdeta Takvîm'in ilavelerle yeniden yazılmış bir versiyonu" şeklinde bir değerlendirme yapılmıştır. ${ }^{4}$ Diğer taraftan hem Pezdevî hem de Serahsî'nin Takvîmü'l-edille'den pek çok yönden istifade etmekle ve esas itibariyle Cessâs-Debûsî çizgisini devam ettirmekle birlikte Debûsî'nin eserini "bilinçli bir biçimde revize ettikleri" ve onun çokça eleştirilen bazı yönlerini başarılı bir biçimde "törpüledikleri" değerlendirmesi de önem arz etmektedir. Görebildiğimiz kadarıyla bu değerlendirme Pezdevî ve Serahsî'nin Debûsî'nin eserindeki Mutezilî imâları ayıklamada ve temizlemedeki hassasiyetleri çerçevesinde ifade edilmektedir. ${ }^{5}$

Usûlü's-Serahsînin temel kaynaklarının belirlenmesine dair aynı coğrafyada, ortak ders halkalarında yetişmiş ve vefat tarihleri de birbirine çok yakın olan Pezdevî ile Serahsî̀nin usûl eserleri arasındaki ilişkinin tespit edilmesi de önem arz eder. Nitekim bazı değerlendirmelere göre Pezdevî ve Serahsî’nin eserlerinin neredeyse aynı kalemden çıkmış kadar birbirine benzedikleri, bununla birlikte "birinin diğerinin eserinden haberdar olup onu kullandığına dair herhangi bir veri bulunmadığından" dolayı bu iki eserin esas itibariyle müelliflerin müșterek hocaları Halvânî ö. (452/1060) ile birlikte geliștirilmiș ortak bir malzemeye dayandığı ifade edilmektedir. ${ }^{6}$ Usûlü'l-Pezdevî hakkında yapılmış bir araștırmada ise Serahsî'nin büyük ölçüde Pezdevî'nin eserinden yararlandığı ve "adını koymasa da bir bakıma onu şerh ettiği” Pezdevî'nin ise Debûsî'den çokça istifade etmiş olduğundan hareketle Usûlü's-Serahsînnin "Debûsî ve Pezdevî̀nin eserleri üzerine kurulmuş ve bunları bir ölçüde şerh etmiş olduğunun söylenebileceği" ifade edilmiştir. Yazar bu tespitini iki eser arasındaki ileri derecedeki benzerlik, bazı meselelerde aynı ifadelerin tekrar edilmesi ve bazı verilerden hareketle Serahsî'nin eserinin daha sonra yazılmış olduğu tahminine dayandırmaktadır. ${ }^{7}$

Usûlü's-Serahsînnin temel kaynaklarına dair yapılmış olan bazı değerlendirmelere kısaca işaret ettikten sonra bu konuda şunu söyleyebiliriz. Usûlü'sSerahsînnin kaynaklarına dair fikir edinmek için kendisinden önce veya aynı dönemde telif edilmiş olan eserlerin sistematiği ve muhtevası ile mukayese edilmesi isabetli bir yöntem olmakla birlikte Serahsî’nin naklettiği mezhep içi ihtilaflı meselelerde bazen isim vererek bazen ise "meşâyıhımızdan birisi" veya "meşâyıhımızın müteahhirûn âlimlerinden birisi" gibi ifadelerle görüş sahibinin ismini zikretmeden naklettiği görüşlerden ve Serahsî’nin bu görüşlere yönelik itirazlarından da istifade edilebilir.

Serahsî̀nin eserini hazırlarken yararlandığı kaynaklardan biri Hanefî usûl li-

\footnotetext{
${ }^{4}$ Yetkin, Hanefî Usûlünün Kurucularından Debûsî ve Usûl Anlayıșı, 46.

${ }^{5}$ Bedir, Fıkı Mezhep Sünnet, 40-41, 146.

${ }^{6}$ Mürteza Bedir, "Usûlü’s-Serahsî”, Türkiye Diyanet Vakfı İslam Ansiklopedisi (İstanbul: TDV Yayınları, 2012), 42/221; Mürteza Bedir-Ferhat Koca, "Pezdevî”, Türkiye Diyanet Vakfı İslam Ansiklopedisi (İstanbul: TDV Yayınları, 2007), 34/265.

${ }^{7}$ Mehmet Boynukalın, “Hanefî Usûl Muhtasarlarının Gelişimi: (I) Usûlü’l-Pezdevî ve Hanefî Usûlündeki Yeri”, İslam Hukuku Araștırmaları Dergisi 30 (2017), 508-509. Bu iki eser arasındaki kapsam, konu başlıkları ve kullanılan ifadeler itibariyle mevcut benzerlik açıtır.
} 
teratürünün ilk kapsamlı eseri olan Cessâs'ın el-Fusûl fi'l-usûl'üdür. Eserinin muhtelif kısımlarında Cessâs'ın görüș ve nakillerine yer veren Serahsî âmm lafız konusunu işlerken Cessâs'ın âmm lafız tanımını nakleder ve bu tanımı hatalı bulur. Daha sonra Cessâs'ın "kitabında" bu mesele ile irtibatı bulunan müşterek lafzın umum ifade etmediği prensibini açık bir şekilde naklettiğini söyler. Bundan dolayı Cessâs'ın âmm lafzı sehven hatalı tarif etmiş olabileceğini ya da zikredilen tanımın tevil edilebileceğini söyleyen Serahsî, Cessâs'ın eserinin "başka bir nüshasında" ise âmm lafzın tanımının kendi yapmış olduğu tevile müsait bir ifade ile zikredildiğini gördügünü ifade eder. ${ }^{8}$ Ayrıca Serahsî eserinin muhtelif kısımlarında Cessâs'a ait bazı görüşleri doğrudan ona nispet ederek nakletmekle birlikte Cessâs'ın eserinde zikretmediği bir görüşü ona nispet ederken "ويحكى عن أبي بكر الرازي" şeklinde ihtiyatlı bir ifade kullanmaktadır. ${ }^{9}$

Serahsî'nin Usûl'ündeki temel kaynaklarından bir diğeri Debûsî'nin eseridir. Usûlü's-Serahsînnin esas itibariyle Takvîmü'l-edille'yi takip eden bir üslup ve muhteva içerdiği ifade edilmektedir. ${ }^{10}$ Aşağıda nakledileceği üzere Serahsî eseri boyunca farklı meseleler bağlamında Debûsî'nin Takvîmü'l-edille'de zikrettiği bazı görüşlerini onun ismini zikretmeksizin "meşâyıhımızdan birisi" ifadesi ile nakledip bu görüşlere itiraz etmektedir. Birkaç meselede de yine açıkça ismini zikretmeksizin Debûsî'nin usûl eserine atıf yapmaktadır. ${ }^{11}$

Pezdevî ve Serahsî̀nin vefat tarihleri birbirine çok yakındır. Bu iki âlimin usûl eserleri; konu başlıkları, ihtiva ettikleri meseleler ve bazı ifadeler bakımından önemli ölçüde benzerlik arz etmektedir. Serahsî̀nin usûl eserini hayatının sonuna doğru kaleme aldığı bilinmektedir. Nitekim Usûlü's-Serahsînnin mukaddimesinde müellifin fürû fikha dair İmâm Muhammed'in eserlerini şerh ettikten sonra 479 senesinin Şevval ayında cumartesi günü bu eseri imlâ etmeye başladığı açıklanmaktadır. ${ }^{12}$ Pezdevî'nin ise eserini büyük ihtimalle daha erken bir tarihte telif etmiş olduğu ifade edilmektedir. ${ }^{13}$ İki eser arasındaki benzerlik ile birlikte değerlendirildiğinde bu bilgiler Usûlü'l-Pezdevî ile Usûlü's-Serahsî arasındaki ilişkiye dair bir fikir vermekte ise de bu konuda kanaatimizce diğer önemli bir veri şudur. Așağıda nakledileceği üzere Usûlü's-Serahsî̉de Pezdevî'nin usûl eserinde zikrettiği bazı görüşlerine yönelik itirazlar söz konusudur. İki eserdeki ifadeler mukayese edildiğinde bu meselelerde Serahsî'nin Pezdevî̀yi kastettiği anlaşılmaktadır. Dolayısıyla Serahsî'nin usûl eserini hazırlarken elinin altındaki kaynaklardan birinin Usûlü'lPezdevî olduğu anlașılmaktadır. Buna göre Usûlü's-Serahsînnin temel kaynaklarının telif tarihi sirasıyla el-Fusûl fi'l-usûl, Takvîmü'l-edille ve Usûlü'l-Pezdevî olduğu ifade

هكذ رأيته في بعض النسخ من كتابه 8 Serahsî, el-Usûl, thk. Ebu'l-Vefâ el-Efgânî (Beyrut: Dâru'l-Kütübi'l-lilmiyye, ts.), $1 / 125$.

${ }^{9}$ Serahsî, Usûl, $1 / 64$.

${ }^{10}$ Bedir-Koca, “Pezdevî”, 34/265; Bedir, “Usûlü’s-Serahsî”, 42/222.

11 Serahsînnin bu ifadeleri aşağıda "Serahsînnin Debûsîye Yönelik İtirazları" başlı̆ı altında nakledilecektir.

12 Serahsî, Usûl, $1 / 10$.

${ }^{13}$ Mehmet Boynukalın, "Hanefî Usûl Muhtasarlarının Gelişimi: (I) Usûlü'l-Pezdevî ve Hanefî Usûlündeki Yeri", 508. 
edilebilir. ${ }^{14}$

Usûlü's-Serahsînnin temel kaynaklarına dair bu kısa açıklamadan sonra Serahsî'nin Hanefî usûl âlimlerine yönelik itirazlarına ve şahsî tercihlerine dair ana hatlarıyla bilgi vererek Debûsî ve Pezdevî’ye yönelik (olduğu anlașılan) itirazlarını zikredebiliriz.

\section{Serahsî̀nin Usûl'de Hanefî Âlimlerine Yönelik Bazı İtirazları}

Serahsî Usûl'ünde meseleleri ele alırken mezhep içi ihtilaflara işaret etmekte ve şahsî tercihlerini ifade etmektedir. Serahsî̀nin "Bana göre”, "Bu konudaki sahih görüş" vb. sarih ifadelerle belirttiği şahsî görüşleri ve tercihleri, genelde nakletmiş olduğu bir görüşe yönelik itiraz formunda zikredilmektedir.

Hanefî usûl literatüründeki mezhep içi ihtilaflı meselelerin tespit edilmesine dair "ashâb" kavramının belli ölçüde önemli olduğu ifade edilebilir. Özellikle ilk dönem eserlerindeki "ashâbımız" ifadesi dar manada Ebû Hanife ve yakın talebelerini yani mezhep imâmlarını ifade etmek üzere, geniş manada ise Hanefî mezhebine müntesip olan fakihleri kastetmek üzere kullanılmaktadır. Mesela Serahsî̀nin "Ashâbımızdan birisi mutlak emrin hükmünü hac ibadetinin derhal yerine getirilmesi gereken ya da ömür boyunca kişinin dilediği zaman yerine getirebileceği bir emir olup olmadığına dair 'ashâbımız' arasındaki meșhur ihtilaf üzerine bina etmiștir." ifadesinde bu iki kullanımın örneğini görmek mümkündür. Nitekim Serahsî bu cümlede "ashâbımızdan birisi" ifadesi ile Kerhî'yi, devamındaki "ashâbımız" ifadesi ile ise Ebû Hanife, Ebû Yûsuf ve İmâm Muhammed'i kastetmiştir. ${ }^{15}$

Serahsî naklettiği mezhep içi ihtilaflı meselelerde Kerhî ve Cessâs gibi bazı Hanefî âlimlerin görüşünü, görüş sahibinin ismini zikrederek nakledip bu görüşü tercih etmediğini ifade etmekte ve şahsî görüşünü belirtmektedir. ${ }^{16}$ Bir meselede de hocası Halvânî̀ye nispet ederek naklettiği bir görüşe itiraz etmektedir. ${ }^{17}$

Serahsî̀nin naklettiği mezhep içi ihtilaflı meselelerin tespitine ve bazı Hanefî usûl âlimlerinin görüşlerine yönelik itirazlarına dair dikkatli bir şekilde takip edilmesi gereken esas kavram "meșâyıh"tır. Serahsî, bazı meselelerde bir bölgenin meşâyıh grubuna işaret ederek mesela "Irak meşâyıhına" nispet ettiği bir görüșe itiraz etmektedir. ${ }^{18}$ Bazı meselelerde ise "meşâyıhımızın çoğu"na nispet ettiği görüşten farklı bir tercihini açıklamaktadır. ${ }^{19}$ Bazen meşâyıhımız veya ashâbımız

14 Serahsî̀nin eserini hazırlarken Debûsî ve Pezdevî'nin eserlerinden daha çok istifade ettiği görülmektedir. Bununla birlikte temel konu başlıkları ve meseleler itibariyle muhteva ve üslup bakımından hangisinin ne ölçüde etkili olduğuna dair net bir kanaat ifade edebilmek için bu üç eserin kapsamlı bir mukayeseye tabi tutulması gerekmektedir.

${ }^{15}$ Serahsî, Usûl, 1/28-29. "Ashâbımız" ifadesi ile mezhep imâmlarının kastedildiği bir örnek için bk. Ebû Bekr er-Râzî Cessâs, el-Fusûl fi'l-usûl, thk. Uceyl Câsim en-Neșemî (Kuveyt: Vizâretü'l-Evkâf, 1994), IV, 283.

16 Örnek için bk. Serahsî, Usûl, 1/26, 64, 94-97, 144.

17 Serahsî, Usûl, 1/319-320. Serahsî, görüşüne itiraz ettiği bu mesele dışında hocası Halvânî’yi eserinin herhangi bir yerinde anmamaktadır.

18 Örnek için bk. Serahsî, Usûl, 1/195.

${ }^{19}$ Serahsî, Usûl, 1/133-142, 281-282. 
kaydını da düşmeden sadece "birisi (bazlları)" gibi bir ifade ile yine Hanefî bir âlime itiraz etmektedir. ${ }^{20}$ Serahsî, pek çok meselede ise "meşâyıhımızdan birisi (bazıları)", "meşâyıhımızın müteahhirûn âlimlerinden birisi (bazıları)" yine bazen "ashâbımızdan birisi (bazıları)" şeklinde açıkça bir isim zikretmeksizin naklettiği görüşü eleştirmekte veya zikredilen görüşü tercih etmediğini ifade edip kendi kanaatini belirtmektedir. ${ }^{21} \mathrm{Bu}$ meselelerde Serahsî'nin görüş sahibinin ismini zikretmeksizin naklettiği görüşün hangi Hanefî âlime ait olduğunun tespit edilmesi Hanefî usûl tarihi açısından önem arz etmektedir.

Usûlü's-Serahsî̉de Debûsî ve Pezdevî'nin isimleri hiç zikredilmemektedir. Bununla birlikte Serahsî’nin açıkça isim zikretmeksizin itiraz ettiği bazı görüşlerin Debûsî ve Pezdevî'ye ait olduğu görülmektedir. Serahsî’nin görüş sahibinin ismini zikretmeksizin naklettiği bazı görüşlerin Debûsî ve Pezdevîye ait olduğu bu iki âlimin usûl eserlerindeki ifadeleri ile mukayese edilmek suretiyle gösterilmeye çalışılacaktır. Debûsî ve Pezdevî̀ye yönelik olduğu tespit edilen itirazlar zikredildikten sonra Usûlü's-Serahsî açısından Takvîmü'l-edille ve Usûl-i Pezdevî̉nin kaynaklık durumuna dair bir değerlendirme yapılacaktır.

\subsection{Serahsî̀nin Debûsî̀ye Yönelik İtirazları}

Yukarıda ifade edildiği üzere Serahsî bazı usûl âlimlerinin -Hanefî mezhebine müntesip olduğunu ifade etmekle birlikte- ismini zikretmeksizin görüşlerini nakledip bu görüșlerin bazılarına yönelik itirazlarda bulunmaktadır. İlgili meseleler Takvîmü'l-edille'deki açıklamalar ile mukayese edildiğinde bu meselelerin bir kısmında Serahsî̀nin, Debûsî’nin görüşlerine itiraz ettiği görülmektedir.

Serahsî, Debûsî̀ye yönelik itirazları arasında özellikle iki meselede eleştirdiği görüşün Sünnî kelam düşüncesi ile uyumlu olmayıp Mutezile'nin benimsediği ilkelerle uyumlu olmasına vurgu yapar. Bu sahadaki bazı araștırmalarda da zikredilen bu iki meseleden biri hüsün-kubuh konusunda mutlak emrin muktezâsl, diğeri ise illetin tahsisi meselesidir. ${ }^{22}$ Bu konunun ve ilgili meselelerin detaylı bir tartışması bu çalışmanın amacını ve sınırlarını aşacağı için bu meselelere kısaca işaret edilip daha sonra Serahsî’nin, Debûsî’nin diğer bazı usûl görüşlerine yönelik itirazları zikredilecektir.

20 Mesela Serahsî görüşüne itiraz etmek üzere başka bir eserinde "ashâbımızın müteahhirûn âlimlerinden birisi (من المتأخرين من أصحابنا)" olarak tarif ettiği kişiyi Usûl'de müntesip olduğu mezhebe işaret etmeksizin sadece "sözüne itimat edilmeyecek birisi (بعض من لا يعتمد على قوله)" olarak nitelendirmektedir. bk. Serahsî, Usûl, 1/73; Serahsî, Şerhu Siyer-i Kebîr, (Beyrut: Dâru'l-Kütübi'lİlmiyye, ts.), 5/368.

21 Örnek için bk. Serahsî, Usûl, 1/20, 370; 2/26.

22 Mürteza Bedir, Debûsî̀nin aklî deliller risalesinin onun Mutezilî eğilimlere sahip olduğunu gösterdiğini ifade eder ve Sünnî anlayıșa aykırı bazı fikirleri benimsemiş olduğuna dair en önemli örnek olarak hüsün-kubuh meselesine ilişkin görüşlerine ve illetin tahsisi meselesindeki görüş ve ifadelerine işaret eder. bk. Bedir, Fıkıh Mezhep Sünnet, 34, 40-41. 


\subsubsection{Kelâm ile Doğrudan İrtibatlı Meseleler}

\subsubsection{Hüsün-Kubuh Tartışması}

Serahsî mutlak emrin muktezâsını "emredilen şeyin şer'an hasen olması" şeklinde açıklayıp hasen niteliğinin emredilen şeyde bizatihi (bi-nefsihî) sabit olmadığını ifade eder. Devamında ise şöyle söyler: "Meşâyıhımızdan birisinin iddia ettiği gibi hüsün-kubuh niteliklerinin 'aklen sabit' olduğu görüşünü benimsemiyoruz. Çünkü akıl bize göre hüküm koyucu (mûcib) değildir."23

Serahsî’nin burada itiraz ettiği ve görüșünü eleștirdiği kiși Debûsî'dir. Nitekim Debûsî̀ye göre bir şeyin emredilmesi, o şeyin Allah katında hakikat anlamıyla hasen olduğunun göstergesidir. Debûsî, hüsün ve kubuh niteliklerinin, emir ve nehyin muktezâsı olduğunu ifade eder. ${ }^{24}$ Görebildiğimiz kadarıyla Pezdevî bu tartışmaya doğrudan değinmemektedir. ${ }^{25}$

\subsubsection{Illetin Tahsisi}

Serahsî illetin tahsisi tartışmasına dair açmış olduğu başlıkta illetin tahsisini tecviz eden görüşün fasid olduğunu ifade etmektedir. Serahsî bu konuda Hanefî âlimlerinden (ashâbımız) birisinin şerî illetlerde tahsisin caiz olduğunu ve bu görüşün selef âlimlerinin yoluna ve ehlisünnet mezhebine aykırı olmadığını iddia ettiğini nakletmektedir. Serahsî, bunun büyük bir hata olduğunu belirterek meselenin önemini şu şekilde ifade etmektedir: "Selef âlimlerimizin görüşüne göre şerî illetlerin tahsisi caiz değildir. Bunu caiz kabul eden kişi ehlisünnete muhalefet etmiş ve temel prensipleri konusunda Mutezile'nin görüşlerine meyletmiş olur."26 Serahsî naklettiği mezhep görüşünü naklî ve aklî delillerle savunduktan sonra illetin tahsisini caiz görmenin tüm müçtehitlerin isabet ettiğini savunmak, ayrıca aslah düşüncesini, el-menzile beyne'l-menzileteyn görüșünü ve büyük günah işledikleri hâlde tövbe etmeden ölen kimsenin ebedi olarak cehennemde kalacağı fikrini benimsemek anlamına geldiğini söylemektedir. ${ }^{27}$

Kerhî, Cessâs ve Debûsî illetin tahsisinin caiz olduğu görüşünü benimsemişlerdir. Bununla birlikte Serahsî'nin bu meseledeki eleştirisinin odağındaki ismin Debûsî olduğu ifade edilebilir. Nitekim Debûsî, illetin sıhhatini tespit etme yöntemi olarak tard yerine tesiri kabul etmenin illetin tahsisini kabul etmeyi gerektireceğini ifade eder. Serahsî ise yukarıdaki açıklamalarıyla birlikte ilgili faslın girișinde Debûsî̀ye cevap olarak illetin sıhhatini tespit yöntemi olarak tardı kabul etmemelerinin illetin tahsisini kabul ettikleri anlamına gelmediğini söyler. ${ }^{28}$

\footnotetext{
${ }^{23}$ Serahsî, Usûl, $1 / 60$.

${ }^{24}$ Debûsî, Takvîmü'l-edille, 44; Yetkin, Hanefî Usûlünün Kurucularından Debûsî ve Usûl Anlayışı, 100-101.

25 Ebü'l-Usr Fahru'l-İslâm el-Pezdevî, el-Usûl (șerhi Keșfü'l-esrâr ile birlikte), thk. Abdullah Mahmud Muhammed (Beyrut: Dâru'l-Kütübi'l-İlmiyye, 1997), 1/272 vd.

${ }^{26}$ Serahsî, Usûl, $2 / 208$.

27 Serahsî, Usûl, 2/211-212.

28 Debûsî, Takvîmü'l-edille, 312; Yetkin, Hanefí Usûlünün Kurucularından Debûsî ve Usûl Anlayışı, 123124. Cessâs ise illetin tahsisi görüșünü mezhep âlimlerine nispet ettikten sonra bu görüșü istihsan anlayışı ile temellendirmektedir. bk. Cessâs, Fusûl, 4/255-256. Kerhî’nin de istihsan görüşünün illetin
} 
"Bâbu fesâd-i tahsîsi'l-ilel" başlığı altında aynı meselelere temas eden Pezdevî de Serahsî ile aynı kanaattedir. Serahsî gibi Pezdevî de bu görüșü benimsemenin Mutezile'nin temel ilke ve prensiplerine götüreceği endişesini dile getirmektedir. ${ }^{29} \mathrm{Bu}$ bağlamda özellikle ictihadda isabet meselesine atıf yapan Pezdevî "Her müctehid hata da eder, isabet de eder" ifadesinin Mutezile'den zâhiren ve bâtınen kaçınmak için tercihe şayan olduğunu ifade eder. ${ }^{30}$

\subsubsection{Usûl-i Fıkha Dair Bazı Meseleler}

Yukarıda nakledilen iki mesele dışında Serahsî, eserinin muhtelif kısımlarında Debûsî'nin bazı usûl görüşlerine itiraz etmektedir. Serahsî̀nin bu itirazlarını Usûl'deki sırası ile nakledeceğiz.

\subsubsection{Orucun Vücub Sebebi}

Serahsî, sebep konusunu işlerken orucun vücub sebebinin mükellefin Ramazan ayına erişmesi olduğunu ifade etmektedir. Bu konuda bazı açıklamalar yaptıktan sonra "Kim Ramazan ayına erişirse o ayı oruç tutarak geçirsin!" (Bakara, 2/185) âyetini zikreden Serahsî şöyle bir nakilde bulunur: "Bu alanda (usûl-i fikh) kitap telif etmiş olan 'müteahhirûn âlimlerinden birisi' orucun vücub sebebinin geceler değil gündüz vakitleri olduğunu zannetmiştir. Gerekçesi ise oruç ibadetinin eda edilebilmesi için elverişli olan vakitlerin sadece gündüz vakitleri olmasıdır." Serahsî daha sonra "Bana göre bu görüş hatalıdır!" diyerek vücubun sebebiyeti bakımından gündüz ve gecelerin eşit olduğunu ifade etmektedir. ${ }^{31}$

Serahsî’nin bu meseledeki "hatalı" görüşü nispet ettiği kişi Debûsî’dir. Nitekim Debûsî Ramazan ayının gecelerinde yiyip içmek mübah olduğuna ve geceleri oruç tutmak caiz olmadığına göre âyetteki eș-şehr (Ramazan ayı) ifadesinden gündüzlerin kastedildiğinin anlaşıldığını ifade etmektedir. Devamında da "Geceleri orucun eda edilmesinin caiz olmaması gecelerin vücub sebebi olmaktan çıkmasına delalet etmez!" şeklindeki muhtemel bir itiraza cevap vermektedir. ${ }^{32}$ Pezdevî de bu konuda aynı gerekçelerle Debûsî̀nin görüşünü benimsemektedir. ${ }^{33}$

\subsubsection{Edatının Anlamı}

Serahsî (أو) edatının temelde vazedildiği anlam itibariyle zikredilen iki şeyden birinin kastedilmiş olduğunu ifade etmek üzere kullanıldığını söyler. Yemin keffâreti örneğini nakleden Serahsî bazı insanların iddiasının aksine ${ }^{34}$ mezhepteki

tahsisi görüşünü benimsemek anlamına geldiğine dair ifadeleri nakledilmektedir. bk. Abdülazîz elBuhârî, Keş̧ü'l-esrâr, thk. Abdullah Mahmud Muhammed (Beyrut: Dâru'l-Kütübi'l-İlmiyye, 1997), $4 / 56$.

${ }^{29}$ Pezdevî, Usûl, 4/46, 51, 53-54.

${ }^{30}$ Pezdevî, Usûl, 4/25, 44. Aynı ifadeyi Serahsî de kullanmaktadır. bk. Serahsî, Usûl, 2/142.

${ }^{31}$ Serahsî, Usûl, 1/104.

32 Debûsî, Takvîmü'l-edille, 62-63.

33 Pezdevî, Usûl, 2/505.

${ }^{34}$ Pezdevî de bu görüşü "bazılarına" nispet etmektedir. Daha sonraki bazı usûl eserlerinde bu görüş Irak 
sahih görüşe göre kişi yemin keffâretinde zikredilen seçeneklerin hepsini de yerine getirmiş olsa sadece biri ile vacibi eda etmiş olur, der. Serahsî daha sonra (أو) edatının vazedildiği esas anlamın ne olduğu konusunda mezhep içi farklı bir görüş nakletmektedir: "Meșâyıhımızdan birisi asıl itibariyle bu edatın teșkîk bildirmek için vazedildiğini zannetmiştir.” Devamında bu kişiye göre emir ve nehy gibi inşâi cümlelerde ise teşkîk anlamı imkânsız olduğu için bu edatın tahyîr anlamına hamledileceği değerlendirmesini nakleden Serahsî bu kişinin zikrettiği görüşü kitabında (fî tasnîfihî) detaylı bir şekilde ele aldığını ifade eder. Serahsî bu açıklamalarından sonra naklettiği görüş ile ilgili "Bana göre bu görüşs sahih değildir." diyerek (أو)

harfinin asıl itibariyle tahyîr bildirmek için vazedildiğini, bundan dolayı emir ve nehy gibi inşâî cümlelerde tahyîr bildirdiğini, ihbârî cümlelerde ise sözün mahalline itibarla şek bildirdiğini ifade eder. ${ }^{35}$

Serahsî'nin bu meselede görüşüne itiraz ettiği kişi Debûsî'dir. Nitekim Debûsî bu meselede âlimlerin büyük çoğunluğunun (أو ) edatının olumlu cümlede tahyîr, olumsuz cümlede ise nefy bildirmek için vazedildiği görüşünde olduklarını naklettikten sonra kendi görüşüne göre ise (أو) edatının teşkîk ifade ettiğini söylemektedir. ${ }^{36} \mathrm{Bu}$ konuda Pezdevî de Serahsî ile aynı görüştedir. Ancak Usûl-i Pezdevĩde Serahsî̀nin eserindeki "meşâyıhımızdan birisi", "kitabında detaylı bir şekilde açıklamıştır" gibi ifadelerle görüşüne itiraz edilen kişiye yönelik vurgu yapılmayıp sadece "Şek bildirmek için vazedilmemiştir." ifadesi ile Debûsî’nin görüşüne dolaylı bir gönderme ile yetinilmiştir. ${ }^{37}$

\subsubsection{Hazf ile İktizâ Ayrımı}

Serahsî umûmu'l-muktezâ meselesini ele alırken şöyle bir ifade kullanmaktadır: "Bu alanda (usûl-i fıkh) kitap telif etmiş birisinin mahzûf ile muktezâyı eşitlediğini gördüm."38 Bu kişinin zikrettiği örnekleri nakleden Serahsî devamında kendi kanaatini şu şekilde ifade eder: "Bana göre bu görüş hatalıdır (sehv). Mahzûf ile muktezâ birbirinden farklı şeylerdir." Serahsî kendi kanaatini ifade ettikten sonra benimsediği görüşü temellendirmek üzere detaylı açıklamalar yapmaktadir. ${ }^{39}$

Serahsî'nin, kitabına da atıf yaparak bu meseledeki görüşünü eleştirdiği kişi Debûsî'dir. Nitekim Debûsî Serahsî̀nin hazf olduğu için iktizâdan ayrıștırılması gerektiğini söylediği örnekleri Takvîmü'l-edille'de iktizâ örneği olarak nakletmektedir. ${ }^{40}$ Pezdevî de bu konuda Serahsî ile aynı kanaattedir. Usûl-i Pezdevî́de mahzûf

Hanefîlerine ve Mutezile'ye nispet edilmektedir. Cessâs ise usûl eserinde mezhepteki hâkim görüşü benimsemektedir. bk. Cessâs, Fusûl, 2/149; Pezdevî, Usûl, 2/223; Şeyh Ahmed Molla Civen, Nûru'lenvâr ale'l-Menâr (Beyrut: Dâru'l-Kütübi'l-İlmiyye, ts.), 1/315.

${ }^{35}$ Serahsî, Usûl, 1/213.

${ }^{36}$ Debûsî'nin açıklamaları için bk. Debûsî, Takvîmü'l-edille, 165-167.

${ }^{37}$ Pezdevî, Usûl, 2/213.

قد رأيت لبعض من صنّف في هذا الباب أنه...

${ }^{39}$ Serahsî, Usûl, 1/251-254.

40 Debûsî, Takvîmü'l-edille, 136-138. 
ile muktezânın ayrı şeyler olduğu, ancak ilk başta kişinin ayırt etmesinin zor olabileceği ifade edilmektedir. ${ }^{41}$

\subsubsection{Nassın İşareti ile Sabit Olanın Tahsisi}

Serahsî yukarıdaki meselenin devamında nassın iktizâsı ve nassın delâleti ile sabit olanın tahsis ihtimaline kapalı olduğunu ifade ettikten sonra nassın işareti konusunda şöyle söyler: "Meşâyıhımızdan birisine göre nassın işareti ile sabit olan da tahsise ihtimalli değildir." Devamında bu görüşün gerekçesini nakleden Serahsî kendi kanaatine göre ise nassın ișareti ile sabit olanın nassın ibaresi ile sabit olan gibi tahsise ihtimalli olduğunu belirtmektedir. ${ }^{42}$

Serahsî̀nin bu konudaki görüșüne itiraz ettiği kişi Debûsî'dir. Nitekim Debûsî yukarıdaki meselenin devamında iktizâ ve delâletin tahsise ihtimali olmadığı gibi nassın işaretinin de tahsise muhtemel olmadığını ifade etmektedir. ${ }^{43}$

\subsubsection{Bidat Ehlinin Muhalefetinin İcmanın Gerçekleșmesine Etkisi}

Serahsî icmanın teşekkülüne dair mezhep görüşünü şöyle açıklamaktadır: "Hüccet olan icma, her dönemde bidat (hevâ) ehline mensup olup da fiskını ilan edenler dışındaki bütün âlimlerin ittifakı ile gerçekleşir." Daha sonra bidat ehlinden olduğu bilindiği hâlde insanları bu görüsse davet etmeyen kişilere dair "meşâyıhımızdan birisi”nin şu görüşü benimsediğini nakletmektedir: "Bu kişinin dalâlete nispet edildiği konudaki görüşü muteber değildir. Ancak bunun dışındaki görüşü muteber olup o kişinin muhalefetine rağmen icma sabit olmaz. Nitekim bu kişi şahitlik yapmaya ehildir." Serahsî devamında kendi kanaatine göre sahih olan görüşü şu şekilde ifade eder: "Kişi bidat ehli olmakla itham ediliyor ancak bidat görüșünü izhar etmiyorsa bu durumda hüküm yukarıda görüşü nakledilen şahsın söylediği gibidir. Fakat bidat görüşünü izhâr ediyorsa bu durumda icmanın gerçekleşmesi konusunda onun görüşüne itibar edilmez." ${ }^{44}$

Serahsî”nin bu meselede "meşâyıhımızdan birisi"ne nispet ederek naklettiği ve benimsemediği görüş Debûsî”ye aittir. Nitekim Debûsî bidat ehlinin bidata nispet edildikleri konudaki muhalefetlerine itibar edilmeyeceğini ancak küfre düşmedikçe veya çok aşırıya gitmedikçe bunun dışındaki konulardaki muhalefetlerinin muteber olduğunu ifade etmektedir. ${ }^{45}$ Pezdevî de bu konuda Serahsî ile aynı kanaattedir. Serahsînnin sahih olduğunu ifade ettiği görüş doğrultusunda onun açılklamaları ile paralel ifadelere yer vermektedir. ${ }^{46}$

\subsubsection{Cevâmiu'l-Kelim Türünden Olan Hadisleri Mana ile Nakletme}

Serahsî hadislerin mana ile nakledilmesi meselesinde hadis lafızlarının ma-

\footnotetext{
41 Pezdevî, Usûl, 2/360-362.

42 Serahsî, Usûl, 1/254.

43 Debûsî, Takvîmü'l-edille, 139.

${ }^{44}$ Serahsî, Usûl, 1/311.

${ }^{45}$ Debûsî, Takvîmü'l-edille, 28.

46 Pezdevî, Usûl, 3/351-353.
} 
hiyetine göre bir taksim yaptıktan sonra cevâmiu'l-kelim türünden olan hadis lafızlarına dair "meşâyıhımızdan birisi"nin zâhir lafız türünde belirtilen şartlara riayet edilmesi durumunda mana ile nakledilmesini caiz gördüğünü ifade eder. Serahsî ise bu tür lafızları ifade etme kabiliyetinin hususi olarak Hz. Peygamber'e verilmiş olmasından dolayı bu hadislerin mana ile nakledilmesinin caiz olmadığı görüşündedir. 47

Serahsî'nin bu meselede itiraz ettiği kişi muhtemelen Debûsî'dir. Nitekim Debûsî bu meseleyi işlerken cevâmiu'l-kelim türü hadislerin mana ile nakledilemeyeceğine dair bir kayıt düşmemektedir. Dolayısıyla zikredilen şartlara riayetle bu tür hadislerin de mana ile rivayet edilebileceği görüşünü benimsediği anlaşılabilir. ${ }^{48}$ Serahsî ile paralel açıklamalar yapıp aynı tercihte bulunan Pezdevî de görüşü eleștirilen kişinin cevâmiu'l-kelim türü hadisleri diğer türlerden ayırt etmediğini belirtmektedir. ${ }^{49}$

\subsubsection{Yazılı Bir Metnin Rivayeti}

Serahsî yazılı bir metnin rivayet edilmesi durumunda kendisine icazet verilen kişinin yazılı metnin içerisinde ne olduğuna dair bilgi sahibi olmasının şart olduğunu söyler ve şöyle devam eder: "Eğer kendisine icazet verilen kişi yazılı metnin içerisinde ne olduğunu bilmiyorsa 'meşâyıhımızdan birisi'ne göre bu durumda hüküm Ebû Hanife, Ebû Yûsuf ve İmâm Muhammed'in kadının bir başka kadıya mektup yazması meselesi veya şahitlik bölümündeki ihtilaflarına kıyasla Ebû Hanife ve İmâm Muhammed'e göre bu icazet sahih değil iken Ebû Yûsuf'a göre sahihtir. Nitekim şahidin mektubun içerisinde ne olduğunu bilmesi Ebû Hanife ve İmâm Muhammed'e göre şart iken Ebû Yûsuf'a göre şart değildir." Serahsî bu görüşü naklettikten sonra kendi görüşünü ise şöyle ifade eder: "Bana göre doğrusu şudur: $\mathrm{Bu}$ tür bir icazet, onların hepsine göre ilke olarak sahih değildir. Fakat Ebû Yûsuf burada zaruret gerekçesi ile istihsanı esas alarak sıhhat görüşünü benimsemiştir." 50

Serahsî̀nin bu meselede "meşâyıhımızdan birisi”ne nispet ederek naklettiği görüş Debûsî̀ye aittir. Nitekim Debûsî yazılı bir metni rivayet etme ile ilgili meseledeki kuralı naklettikten sonra bu konunun Hanefî imâmlarının -kitâbü'l-kâdî bölümünde nakledilen- şahidin mektubun içerisinde ne olduğunu bilmemesi durumunda şahitliğinin batıl olması görüşü ile aynı olduğunu ifade eder. Bunun Ebû Hanife ve İmâm Muhammed'in görüşü olduğunu belirten Debûsî, Ebû Yûsuf'un ise mektubun kendisi ve şekli tanındığı durumda şahitliğin caiz olduğu görüşünü benimsediğini nakleder. Debûsî, Ebû Hanife ve İmâm Muhammed'in görüşünün ihtiyata uygun olduğunu ifade ederek bu bahsi sonlandırmaktadır. ${ }^{51}$

\footnotetext{
47 Serahsî, Usûl, 1/357.

48 Debûsî, Takvîmü'l-edille, 195.

${ }^{49}$ Pezdevî, Usûl, 3/89.

50 Serahsî, Usûl, 1/377-378.

51 Debûsî, Takvîmü'l-edille, 192.
} 


\subsubsection{8. Şart Edatının Işslevi}

Serahsî şart konusunu işlerken, şart edatının zikredilmesi durumunda şart manasının bulunduğunu ifade etmektedir. Daha sonra bu konuda "meşâyıhımızın müteahhirûn âlimlerinden birisi"ne nispet ettiği mükâtebe âyetiyle ilgili şu değer-

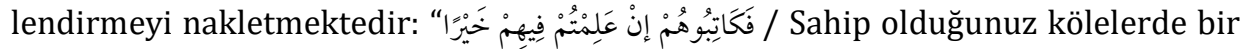
hayır görürseniz onlarla mükâtebe akdi yapın! (Nûr, 24/33) âyetindeki şart ifadesi âdete uygun olarak (bi tarîki'l-âdet) zikredilmiștir. Zikredilen durumda mükâtebe akdine daha fazla ihtiyaç duyulması manası dışında şart edatının herhangi bir ilave anlamı yoktur." Serahsî bu görüşü naklettikten sonra kendi kanaatini şu şekilde ifade eder: "Bana göre bu güçlü bir tespit değildir. Çünkü bu ifadenin zımnında bu âyette zikredilen şart edatının şart ifade etmediğine dair bir mana vardır. Allah'ın kelâmı ise bundan münezzehtir. Aksine bu âyetteki şart edatının şart anlamı mevcuttur." Serahsî kanaatini bu şekilde açıkladıktan sonra buradaki şart edatının normalde mübah olan mükâtebe akdinin âyette zikredilen șartın varlığı durumunda mendub olacağı şeklinde bir anlamı olduğunu söylemektedir. ${ }^{52}$

Serahsî bu meselede Debûsî'nin görüşüne itiraz etmektedir. Nitekim Debûsî zikrettiği dört şart türü arasında "suret itibariyle şart olup mana itibariyle şart olmayan" kısmında bu âyeti nakledip şart edatının gerçekten şart manası ifade etmeksizin âdete uygun olarak zikredildiğini söylemektedir. Şart ifadesinin zikredilmesi ile zikredilmemesinin bu bakımdan bir farkı olmadığını ifade eden Debûsî̀ye göre şart edatının tek faydası (anlamı) zikredilen durumda daha çok ihtiyaç olması bakımından evleviyet ifade etmesidir.53 Debûsî burada mükâtebe âyetiyle birlikte şartın aynı türüne örnek olmak üzere iki âyet daha nakleder. Serahsî ise Debûsînnin mükâtebe âyetiyle birlikte naklettiği bu âyetlerde de aynı şekilde şart edatının mendubluk ifade ettiğini söyler. ${ }^{54}$

Pezdevî de aynı konuyu işlerken "bir kişinin" mükâtebe âyetindeki şart edatı ile ilgili olarak âdeten bir şart edatı olduğu görüşünü nakledip bunun doğru olmadığını ifade eder. Bu görüşün tercih edilmesi durumunda âyetteki şart edatının herhangi bir anlam ifade etmeyip ișlevsiz (lağv) kalacağını söyleyen Pezdevî, Kur'ân'ın ise bundan münezzeh olduğunu söyler. Devamında yukarıda nakledilen Serahsî'nin açıklamaları ile paralel bir şekilde âyetteki şart edatının ilgili durumda mükâtebe akdinin müstehab olması şeklinde bir anlam ifade ettiğini söyleyen Pezdevî, ardından Debûsî̀nin naklettiği âyetleri de içeren diğer bazı âyetlerden aynı şekilde şart edatının sünnet, mendub gibi hükümler bildirmesine dair örnekler nakleder.55

\subsubsection{9. Çocuk Hakkında Vücub}

Serahsî çocuk hakkındaki vücub meselesine dair "meşâyıhımızdan birisi şöyle iddia etti" diyerek şu görüşü nakleder: "Zimmetin uygun olması dolayısıyla

\footnotetext{
52 Serahsî, Usûl, 2/321.

53 Debûsî, Takvîmü'l-edille, 386.

${ }^{54}$ Serahsî, Usûl, 2/321-322.

55 Pezdevî, Usûl, 4/289-291.
} 
Allah hakları doğduktan itibaren vacip olmaktadır. Ancak bazı hükümler çocukluk mazereti sebebiyle sakıt olur." Bu görüş sahibi açısından çocuk hakkında "zimmet ile vücubu gerektiren sebeplerin mevcut olduğu" gerekçesini nakleden Serahsî daha sonra bu görüşün tam karşısında konumlandırdığı bir görüş daha nakleder. Yine "meşâyıhımızdan birisi"ne nispet ettiği bu iddiaya göre ise vücub ancak buluğ ile akıl bakımından itidale erişildikten sonra sabit olur. Bu iki görüşü ifrat ve tefrit olarak nitelendiren Serahsî kendi yaklaşımını (tarik-i sahîh) şu șekilde ifade eder: "Sebep ve mahal bulunduktan sonra vücubun hükmüne salahiyetin varlığı ile vücub sabit olur."56

Serahsî'nin itiraz ettiği ilk görüş Debûsî'ye aittir. Nitekim Debûsî insanın doğumuyla birlikte Allah haklarının vacip olduğunu ancak çocukluk mazereti sebebiyle bazı hükümlerin düştüğünü ifade eder. ${ }^{57}$ Serahsî'nin eleștirdiği ve benimsemediği diğer görüş ise Pezdevî̀ye aittir. Aşağıda “Serahsî̀nin Pezdevî’ye Yönelik İtirazları" başlı̆̆ı altında bu konuya tekrar değineceğiz. ${ }^{58}$

\subsubsection{Değerlendirme}

Serahsî̀nin Usûl adlı eserindeki Hanefî usûl âlimlerine yönelik itirazları arasından "ashâbımızdan birisi", "meşâyıhımızdan birisi" veya "meşâyıhımızın müteahhirûn âlimlerimizden birisi" gibi ifadelerle isim zikretmeden nakledip eleştirdiği ve itiraz ettiği görüşlerin bir kısmının Debûsî'ye ait olduğu görülmektedir. Yukarıda nakledilen bu meselelerden ikisi kelâmî ilke ve prensiplerle ilgisi bakımından ayrıca önemi haizdir. Nitekim Serahsî illetin tahsisi meselesinde Debûsî̀ye yönelik Mutezilî eğilimleri olduğu yönünde bir eleștiri yapmıștır.

Hanefî usûl tarihine dair yapılan araştırmalarda tespit edildiği üzere Serahsî'nin temel kaynaklarından biri Takvîmü'l-edille'dir. Bununla birlikte Serahsî̀nin eser boyunca muhtelif konularda Debûsî'nin görüşlerine itiraz ettiği görülmektedir. Bazıları nispeten detay olarak da nitelendirilebilecek bu meselelerde Serahsî sadece doğru görüşü zikretmekle veya tercih etmediği görüşe işaret etmekle yetinmeyip "meşâyıhımızdan birisi" vurgusu ile kendi kanaatine göre hatalı olan görüşün sahibine yönelik bir eleştiri ve itirazda bulunduğunu ifade etmiş olmaktadır. Bu tavrından hareketle Serahsî̀nin, usûl eserinin temel kaynaklarından biri olan Takvîmü'l-edille'deki görüş ve açıklamaları sıkı bir kontrolden geçirdiğine işaret etmek istediği şeklinde bir değerlendirme yapılabilir. ${ }^{59}$

Bu çalışmada sadece Serahsî̀nin naklettiği mezhep içi ihtilaflı meseleler ve isim zikretmeksizin naklettiği bazı görüşlere yönelik eleştirileri dikkate alınarak Serahsî'nin Debûsî'ye yönelik itirazları tespit edilmiștir. Bunun dıșında Serahsî’nin,

${ }^{56}$ Serahsî, Usûl, 2/333-335.

57 Debûsî, Takvîmü'l-edille, 334, 337, 423-424, 428.

$58 \mathrm{Bu}$ meselenin detaylı bir tasviri için bk. Cüneyd Köksal, "Hanefî Fıkıh Düşüncesinde Vücub-Eda Ehliyeti Ayırımı ve Bu Ayrımla İlişkili İki Mesele”, İstanbul Üniversitesi İlahiyat Fakültesi Dergisi 25 (2011), 115-121.

59 Mesela Serahsî hüsün-kubuh konusunda Debûsî'nin tasnifinden yararlanmakla birlikte ilgili faslın hemen başında Debûsî̀ye yönelik itirazını ifade etmektedir. bk. Debûsî, Takvîmü'l-edille, 44; Serahsî, Usûl, 1/60. 
Debûsî’nin tüm görüşleri hakkındaki kanaatinin ancak daha kapsamlı bir mukayese neticesinde tespit edilmesi mümkün olabilir. Mesela Debûsî bir emrin, mükellef o emre konu olan fiili yapma imkânı bulmadan nesh edilmesinin caiz olmadığı görüşündedir. ${ }^{60}$ Serahsî ise bu görüşün Mutezile'nin görüşü olduğunu ifade etmiş ve nesh için inanma imkânının varlığının yeterli olduğu görüşünü benimsemiştir. Ancak Serahsî bu görüşü naklederken mezhep içi bir ihtilafa işaret etmemektedir. ${ }^{61}$ Mezhep içi ihtilaflı bir mesele olan sahâbî kavlinin hücciyeti konusunda da Serahsî, Ebû Saîd el-Berdaînnin ö. (317/930) görüşünü benimsemiş iken Debûsî'nin meseleyi sunuş tarzı ve açıklamalarından Kerhî̀nin görüşüne eğilimli olduğu anlaşılmaktadır. ${ }^{62}$

\subsection{Serahsî’nin Pezdevî’ye Yönelik İtirazları}

Serahsî'nin Usûl'de "ashâbımızın müteahhirûn âlimlerinden birisi"ne veya "meşâyıhımızdan birisi"ne nispet ederek itiraz ettiği bazı görüşlerin Pezdevî'ye ait olduğu anlaşılmaktadır. Usûl-i Pezdevî deki ilgili meseleye dair zikredilen görüş ve açıklamalar ile mukayese edildiğinde bu durum tespit edilebilmektedir. Şimdi bu meseleleri zikredebiliriz.

\subsection{1. İstihsan ile Hüküm Verilen Bir Meselede Kıyas ile Amelin Hükmü}

Serahsî, istihsan konusunu işlerken şöyle bir nakilde bulunmaktadır: "Ashâbımızın müteahhirûn âlimlerinden birisi istihsan ile hüküm verilen bir meselede kıyas ile amel etmek de caiz olmakla birlikte istihsan ile amel etmenin evlâ olduğunu zannetmiştir. Bunu da müessir illet karşısında tarda benzetmektedir. Nitekim tard ile amel etmek caiz olmakla birlikte müessir illet ile amel etmek evlâdır." Serahsî "Bana göre bu görüş hatalıdır (vehm)" diyerek kendi tercih ettiği görüşün sahih mezhep görüşü olduğuna dair açıklamalar yapmakta ve Hanefî imâmlarının eserlerinden nakilde bulunmaktadır. Buna göre istihsan ile hükmedilen bir meselede kıyas terk edilmiştir ve bu da terk edilmiş olan kıyas ile amel etmenin caiz olmadığını göstermektedir. ${ }^{63}$

Serahsî'nin bu meselede "ashâbımızın müteahhirûn âlimlerinden birisi" diyerek görüşüne itiraz ettiği kişi Pezdevî’dir. Nitekim Pezdevî istihsan konusunu işlerken şu açıklamayı yapmaktadır: "Bize göre istihsan iki kıyastan biridir. Fakat bu isimle anılması diğer kıyas ile amel etmek de caiz olmakla birlikte istihsan ile amel etmenin daha öncelikli (evlâ) olduğuna işaret etmek içindir. Bu aynı müessir illet ile amel etmek evlâ olmakla birlikte tard ile amel etmenin caiz olması gibidir." 64

\footnotetext{
${ }^{60}$ Debûsî, Takvîmü'l-edille, 237.

${ }^{61}$ Serahsî, Usûl, 2/63. Bu konu hakkında bk. Yetkin, Hanefî Usûlünün Kurucularından Debûsî ve Usûl Anlayıșı, 111-112.

${ }^{62}$ Debûsî, Takvîmü'l-edille, 256-257; Serahsî, Usûl, 2/105, 108; H. Yunus Apaydın, "Sahâbî Kavli”, Türkiye Diyanet Vakfi İslam Ansiklopedisi (İstanbul: TDV Yayınları, 2008), 35/503.

${ }^{63}$ Serahsî, Usûl, 2/201.

${ }^{64}$ Pezdevî, Usûl, $4 / 6$.
} 


\subsubsection{Bir Vakte İzafe Edilmiș İcab}

Serahsî illet türlerini ele alırken sebebe benzeyen illet kısmında şöyle söyler: "Meşâyıhımızdan birisi bir vakte izafe edilmiş olan icabı bu türden kabul etmiştir." Bu görüşü kabul etmeyen Serahsî şahsî kanaatini şöyle açıklar: "Bana göre bu konuda sahih olan görüş vakte izafe edilmiş olan icabın isim ve mana bakımından illet olup hüküm bakımından illet olmayan üçüncü türe dahil olmasıdır."65

Serahsî'nin bu meselede "meşâyıhımızdan birisi" diyerek görüşünü nakledip itiraz ettiği kişi Pezdevî'dir. Nitekim Pezdevî illet türlerini ele alırken isim ve mana bakımından illet olup hüküm bakımından illet olmayan türde bazı örnekler nakletmekte ve bunların illet olup sebep olmadığını (كان علة لا سببا) belirtmektedir. Ancak muhtevasında izafe manası bulunan icâre akdinin ve bir vakte izafe edilmiş olan icabın bu türden olduğunu söylemekle birlikte bu iki illetin sebebe benzediğini de ifade etmektedir.66

\subsection{3. Çocuk Hakkında Vücub}

Yukarıda naklettiğimiz üzere Serahsî çocuk hakkında vücub meselesine dair iki farklı görüş nakletmekte ve bunları ifrat-tefrit olarak nitelendirip kendi kanaatini ifade etmektedir. Serahsî'nin "meşâyıhımızdan birisi"ne nispet ederek naklettiği ilk görüş yukarıda ifade ettiğimiz üzere Debûsî’ye aittir. Yine "meşâyıhımızdan birisi"ne nispet ederek naklettiği diğer görüş ise Pezdevî’ye aittir. Nitekim Serahsî'nin itiraz ettiği bu görüşe göre vücub ancak buluğ ile akıl bakımından itidale erişildikten sonra sabit olur. ${ }^{67}$ Pezdevî, bir süre kendisinin de Debûsî'nin benimsediği görüşü benimsediği hâlde daha sonra bu görüşü terk ettiğini ifade etmektedir. Pezdevî’nin daha sağlam bularak tercih ettiği görüșe göre ise buluğ öncesi vücub sabit olmaz. ${ }^{68}$

\subsubsection{Cocuğun Talak Hakkl}

Serahsî, kâsır ehliyet konusunu ele alırken sırf zarar niteliğinde olan talak, azat etme, hibe ve sadaka gibi tasarrufların dünyevî bakımdan herhangi bir menfaat hasıl etmeyeceği dolayısıyla kâsır eda ehliyeti ile bu tasarrufların yapılamayacağını, bu nedenle de çocuğun bu tasarrufları yapmaya yetkisinin bulunmadığını ifade eder. Serahsî bu meselede şöyle bir görüş nakleder: "Meşâyıhımızdan birisi şunu iddia etmiştir: Bu hüküm çocuk hakkında asıl itibariyle meşru değildir. Dolayısıyla çocuğun karısı talaka mahal değildir." Serahsî naklettiği bu görüşe yönelik itirazını şu şekilde ifade eder: "Bana göre bu görüş hatalıdır (vehm). Milk-i nikâh ile talak hakkına da mâlik olunur. Nitekim milkin aslını sabit kılmada çocuğa yönelik herhangi bir zarar yoktur. Zarar ancak bu tasarrufun geçerli kılınmasında söz konusu olabilir." Serahsî daha sonra ihtiyaç (hâcet) durumunda çocuğun sahip ol-

\footnotetext{
${ }^{65}$ Serahsî, Usûl, 2/317.

66 Pezdevî, Usûl, 4/270-273.

67 Serahsî, Usûl, 2/334.

${ }^{68}$ Pezdevî, Usûl, 4/340, 345-348; Buhârî, Keșfü'l-esrâr, 4/346.
} 
duğu talak hakkının kullanılmasının mümkün olduğunu söylemektedir. ${ }^{69}$

Serahsî'nin bu meselede görüşünü nakledip itiraz ettiği kişi Pezdevî'dir. Nitekim Pezdevî, ilgili meselede sırf zarar niteliğindeki talak, azat etme, hibe vb. tasarrufların çocuk hakkında asıl itibariyle meşru olmadığını ifade etmektedir. ${ }^{70}$

\subsubsection{Değerlendirme}

Yukarıda naklettiğimiz üzere Pezdevî ve Serahsî'nin usûl eserleri arasındaki konu başlıkları ve kullanılan ifadeler açısından mevcut olan benzerlik günümüzdeki bazı çalışmalarda ele alınmıştır. Bazı araştırmacılar bu durumun Pezdevî ve Serahsî'nin aynı coğrafyada bulunmaları ve ortak hocaları kanalıyla aynı ilmî mirasa sahip olmaları gerekçesi ile izah edilebileceğini ifade etmişlerdir. ${ }^{71}$ Bazı araştırmalarda ise Serahsî̀nin bu eserini vefatına yakın bir dönemde telif etmiş olduğu bilgisine dayanılarak Pezdevî'den daha sonra telif etmiş olduğuna dair tahmin neticesinde Serahsî̀nin Pezdevî'nin eserini adeta şerh etmiş olduğunun söylenilebileceği ifade edilmektedir. ${ }^{72}$

Serahsî̀nin Pezdevî̀nin usûl eserinden haberdar olduğuna dair elimizde güçlü bir delil bulunmaktadır. Naklettiğimiz bu dört meselede görüldügü üzere Serahsî, bazı meselelerde Pezdevî’nin ismini zikretmeksizin "meşâyıhımızdan birisi" vb. bir ifade ile onun usûl eserinde ifade ettiği görüşünü nakledip bu görüşe yönelik itirazda bulunmaktadır. Dolayısıyla Serahsî’nin usûl eserini yazarken elinin altındaki temel kaynaklardan birinin Usûlü'l-Pezdevî olduğu anlaşılmaktadır.

\section{Sonuç}

Usûlü's-Serahsî̉de pek çok mezhep içi ihtilaf nakledilmektedir. Serahsî, Hanefî usûl âlimlerine nispet ettiği bazı görüşlerin hatalı olduğunu ifade etmekte ve kendi şahsî kanaatini açıklamaktadır. Serahsî, hatalı olduğunu ifade edip itiraz ettiği ve benimsemediği görüşlerin bir kısmının kime ait olduğunu açlk bir ifade ile belirtmektedir. Bununla birlikte pek çok meselede ise itiraz ettiği görüşü "meşâyıhımızdan birisi" veya "ashâbımızdan birisi" ifadesiyle aynı mezhebe müntesip olduğunu belirtmekle birlikte ismini zikretmediği bir âlime nispet ederek nakletmektedir.

Usûlü's-Serahsî̉de Debûsî ve Pezdevî’nin isimleri hiç zikredilmemektedir. Bununla birlikte bu çalışmada Serahsî̀nin mezhep içi ihtilaflı meselelerde ismini zikretmeksizin itiraz ettiği görüşlerin önemli bir kısmında Debûsî̀yi, bazılarında ise Pezdevî’yi kastettiği tespit edilmiştir. Nitekim Serahsî'nin naklettiği görüşe dair ifadeleri bu iki Hanefî usûl âliminin eserlerindeki ilgili meselelere dair görüş ve açıklamaları ile mukayese edildiğinde bu durum açık bir şekilde görülmektedir.

${ }^{69}$ Serahsî, Usûl, 2/348. Buhârî, Pezdevî șerhinde Serahsînnin bu açıklamalarını nakletmektedir. bk. Buhârî, Keşüu'l-esrâr, 4/360-361.

${ }^{70}$ Pezdevî, Usûl, 4/361.

${ }^{71}$ Bedir-Koca, "Pezdevî", 34/265.

72 Boynukalın, "Hanefî Usûl Muhtasarlarının Gelişimi: (I) Usûlüll-Pezdevî ve Hanefî Usûlündeki Yeri", 508-509 
Serahsî'nin usûl eserinin muhtelif kısımlarında Debûsî'nin görüşlerine, birkaç meselede ise Pezdevî'nin görüşlerine itiraz etmiş olduğu bilgisi Usûlü's-Serahsî açısından Takvîmü'l-edille ve Usûlü'l-Pezdevî ile ilgili şöyle bir değerlendirmeyi mümkün kılmaktadır. Serahsî bu eserinde Takvîmü'l-edille'den önemli ölçüde yararlanmış olmakla birlikte bu eserdeki görüş ve değerlendirmeleri dikkatli bir okumaya tabi tutmuştur. Bazıları nispeten detay sayılabilecek olan pek çok meselede ilgili görüşü "meşâyıhımızdan birisi"ne nispet ederek bu görüșe itiraz etmesi de bu yaklaşımını görünür bir şekilde ortaya koyma isteğinin bir sonucu olarak yorumlanabilir. Serahsî̀nin bu eserinde yine ismini zikretmeksizin "meşâyıhımızdan birisi"ne nispet ederek Pezdevî’nin bazı usûl görüşlerini nakletmesi ise Usûlü's-Serahsînnin temel kaynaklarından birinin Usûlü'l-Pezdevî olduğuna dair önemli bir veri olarak değerlendirilmek durumundadır.

Serahsî, Usûl isimli eserinde muhteva ve sistematik bakımından büyük ölçüde Takvîmü'l-edille'den ve Usûl-i Pezdevî́den istifade etmiş olmakla birlikte bu iki eserin hangisinden daha çok istifade ettiği ve bu iki eserden -daha geniş ve tafsilatlı olması dışında- farklı olan yönleri zikredilen üç eserin kapsamlı bir mukayesesi neticesinde tespit edilebilir. Ayrıca Serahsî'nin mezhep içi ihtilaflı meselelerdeki itirazlarının ve şahsî görüşlerinin isabeti ve sonraki Hanefî usûl literatüründeki etkisi ise başka araştırmalarda ele alınması gereken diğer önemli bir konudur.

Funding / Finansman: This research received no external funding. / Bu araştırma herhangi bir diş fon almamıștır.

Conflicts of Interest / Çıkar Çatışması: The author declare no conflict of interest. / Yazar, herhangi bir çıkar çatışması olmadığını beyan eder.

\section{Kaynakça}

Buhârî, Abdülazîz. Keșfü'l-esrâr (Usûlü'l-Pezdevî ile birlikte). thk. Abdullah Mahmud Muhammed. 4 cilt. Beyrut: Dâru'l-Kütübi'l-İlmiyye, 1997.

Apaydın, H. Yunus. "Sahâbî Kavli". Türkiye Diyanet Vakfı İslâm Ansiklopedisi. 35/500-504. İstanbul: TDV Yayınları, 2008.

Bedir, Mürteza. “Takvîmü'l-edille”. Türkiye Diyanet Vakfı İslâm Ansiklopedisi. 39/493-494. İstanbul: TDV Yayınları, 2010.

Bedir, Mürteza. Flkıh Mezhep Sünnet: Hanefi̊ Flkıh Teorisinde Peygamber'in Otoritesi. İstanbul: Dem Yayınları, 2017.

Bedir, Mürteza. "Usûlü’s-Serahsî”. Türkiye Diyanet Vakfi İslâm Ansiklopedisi. 42/221-222. İstanbul: TDV Yayınları, 2012.

Bedir, Mürteza-Koca, Ferhat. "Pezdevî". Türkiye Diyanet Vakfı İslâm Ansiklopedisi. 34/264266. İstanbul: TDV Yayınları, 2007.

Boynukalın, Mehmet. "Hanefî Usûl Muhtasarlarının Gelişimi: (I) Usûlü'l-Pezdevî ve Hanefî Usûlündeki Yeri". İslam Hukuku Araștırmaları Dergisi 30 (2017), 508-509.

Cessâs, Ebû Bekr er-Râzî. el-Fusûl fi'l-usûl. thk. Uceyl Câsim en-Neşemî. 4 cilt. Kuveyt: Vizâratü'l-Evkâf, 1994.

Debûsî, Ebû Zeyd Ubeydullâh. Takvîmü'l-edille. thk. Halil Muhyiddin el-Meys. Beyrut: Dâru'lKütübi'l-İlmiyye, 2001.

Köksal, Cüneyd, "Hanefî Fıkıh Düşüncesinde Vücub-Eda Ehliyeti Ayırımı ve Bu Ayrımla İlişkili İki Mesele”, İstanbul Üniversitesi İlahiyat Fakültesi Dergisi 25 (2011), 105-122.

Molla Civen, Şeyh Ahmed. Nûru'l-envâr ale'l-Menâr, Beyrut: Dâru'l-Kütübi'l-îlmiyye, ts. 
Pezdevî, Ebü'l-Usr Fahru'l-İslâm Ali b. Muhammed. el-Usûl (Keșfü'l-esrâr ile birlikte). thk. Abdullah Mahmud Muhammed. 4 cilt. Beyrut: Dâru'l-Kütübi'l-İlmiyye, 1997.

Serahsî, Şemsüleimme Ahmed. el-Usûl. Nşr. Ebu'l-Vefâ el-Efgânî. 2 cilt. Beyrut: Dâru'lKütübi'l-i̇lmiyye, ts.

Serahsî, Șemsüleimme Ahmed. Şerhu Siyer-i Kebîr. Beyrut: Dâru'l-Kütübi'l-İlmiyye, ts.

Yetkin, Hacer. Hanefî Usûlünün Kurucularından Debûsî ve Usûl Anlayıșı. İstanbul: Marmara Üniversitesi İlahiyat Fakültesi Vakfı Yayınları, 2017. 